\title{
Where Are Our Dead? Hermeneutical Approach to the Memorandum on Tlatelolco, Poem by Rosario Castellanos
}

\author{
Arturo G. Rillo ${ }^{1}$ \\ ${ }^{1}$ Academic Area of Philosophy, Faculty of Medicine / Autonomous University of the State of Mexico, Mexico
}

\begin{abstract}
In Mexico, the events of October 2, 1968 continue to be analyzed. The "Memorandum on Tlatelolco", offers a line of reflection to overcome the national duel of 48 years. From the field of hermeneutics, one deepens in the understanding of the poem of Rosario Castellanos, to find what is not said through the word. The study is developed from three categories of analysis: forgetting, thinking and memory. Two thematic axes are unveiled: nothingness as subject of the student movement of 1968 in Mexico; the suffering inherent in remembering painful events and the awareness of looking at our own death. These elements ratify the understanding of Rosario Castellanos as a critic of the violence that denounces social injustices. They also allow us to conclude that the inner voice of the analyzed text rehabilitates silence, forgetfulness, suffering and the agony of death, as social imaginaries of Mexican culture.
\end{abstract}

Keywords - hermeneutics, Mexico 1968, Rosario Castellanos, student movement, Tlatelolco

\section{INTRODUCTION}

$1968 \ldots$ The world is consternated... Vietnam is shown as the warlike irrationality that led to World War II and gave meaning to the postwar period [1]. Begin to emerge the dead from their anonymous graves and claim more lives... Martin Luther King dies and with him, the "Black Power" that will be manifested in the Olympics of Mexico [2].

The world has been mute, does not understand its future, and in this incomprehension, it delineates the path of intolerance where humanity has traveled during the last 30 years. A road that leads to the expressions of xenophobia, characterized the beginning of the 21st century [3]. Intolerance and xenophobia show a close link in the configuration of the moral life of peoples [4] and at the end of the "cold war", a postwar period is lived where xenophobic attitudes have become globalized.

In this margin of intolerance shown since 1968, will appear the "French May" [5], continues with the "spring of Prague" [6], and concludes with the "slaughter of Tlatelolco" [7]. A spirit travels the world and it is not that of socialism or of Marxism-Leninism, much less the historical and social consciousness of the proletarian class. The spirit that travels the world is apocalyptic, has the power to kill with the sword, embodied in the rider of the 4th horse: that of death [8,9]; and Hades follows it.

It seems that in 1968 the fourth seal was opened and then the voice of the 4th living creature was heard saying: "Come, and see" [9]. And we have looked at the world ever since..., a world that made captivity the instrument of the state to "kill with the sword". The "disappeared"... where are they? Did you live your life or was life your Apocalypse? Where are their bodies...? Do you dwell in Hades?

In this search a female voice rises; Mexican, sensitive to injustice, and criticism of violence. Rosario Castellanos (1925-1974) joins the poetic voices of his time to denounce the silence and oblivion of the massacre of students in the Three Cultures Plaza on October 2, 1968 [10]. In 1973 is published in the book "Poetry is not you", the testimony of the events that shocked the people of Mexico. "Memorandum on Tlatelolco" expresses, according to the commentators, the political conscience of the historical moment in which it lived [11-13]. Criticism of violence, the claim of oblivion, the function of memory, are categories that have been described in analyzing the poem, but, what else does Rosario Castellanos tell us? From the field of hermeneutics one deepens in the understanding of what was said in "Memorandum on Tlatelolco", with the purpose of finding what is not said through the word.

\section{THINKING THE 68 IN MEXICO}

Hades is the habitat of the dead, but it's also the place where life is hidden that is prohibited by the structures of power and expatriate to those who seek to claim the world. Thus, Hades is oblivion, a geographical point that is in opposition to the Garden of Eden, but beyond the hell of the Catholic faith. Therein, lies the truth of the human condition and of life in general; so that access to the knowledge of good, evil and truth has been forbidden [14]. 
For this reason, to seek our dead in Hades we must transit through hell, walking between the evil of humanity to find everything that should not be, which was prohibited by law, but also what should not be known or imagined. The story of " 68 in Mexico is like the Freudian bond with the mother: "has in analysis seemed to me so elusive, lost in a past so dim and shadowy, so hard to resuscitate, that it seemed as if it had undergone some specially inexorable repression" [15].

In Eden is the one who wrote the official story and the anonymous killer. In hell is the wickedness of one who publicly offered a helping hand; and in Hades, are they exiles of the historical life, the expatriate ones of the consciousness of the effective history. To descend to Hades and face our dead face, we must re-live the story never told. Life, like history, is thus, self-explanatory by itself: it is and point; if you live, do not define yourself. History is understood, but it is not repeated. In its event generates those social imaginaries with which it is recreated. Such is the historical reason: a reconstruction of imaginaries that form the memorial of events that are significant to cultural traditions.

In this line of reflection, there is an untold story that gives meaning to our cultural heritage and that transits, from the University of the Sorbonne in May French, to the Three Cultures Plaza of the Massacre of Tlatelolco. It is the story of a red dawn for humanity, in which a red flower blooms from the depths of the human heart. A red flower that is not cultivated by the friendly hand of Jose Marti, but by the famed hand of the rider of the $2^{\text {nd }}$ apocalyptic horse, that has the power to kill each other.

Since then, the horizon from which one looks at life is tinged with a yellow-green color, with brushstrokes of vermilion tone dotted with black on a white background. It is the image of death that imposes itself on the breath of life, but also where history is written; especially that which is not counted or written. "Another time will come distinct from this one / And somebody will say: / You did not speak well. You should have told / other stories" [16], say the poet Angel Gonzalez.

The attention-forgetting movement in the historicity of being-there human, is the condition of reliving the past [17]. Thus, history is not limited to a simple re-construction of facts, on the contrary, it is to re-know, re-live and re-enable past events. In this sense, the position of Gadamer acquires relevance, understanding history as the common destiny of the collectivity, a being-one-with-the-other being one-only, on which solidarities are founded [18]. Solidarity opens horizons to understand history as a happening that continues to make history, and in its becoming, will be lost as the light of the new day is shown at the dawn of a new day.

To think the 68 in Mexico, the only thing that works is the memory. The process of thinking begins precisely because something comes to mind from memory. Paco Ignacio Taibo II recovers the collective memory, but it emphasizes the smallest and sad personal anecdote, because it says: "you can't make legends without anecdotes" [19]. For generations that did not live the events of the Mexican student movement in 1968, it is necessary to borrow the memory to understand how it was possible to take to the streets in spite of the paralysis of fear, or the capacity to live the collective, as well as the vocation of insomnia.

To think implies, first, to meditate on something; which for our case is to move to the student movement of 1968 in Mexico, which in its dialectic became killing and murder. Can we look at each other during the march of silence? Is it possible, to feel the rage and impotence, as well as the fear and the anguish, that flooded the students of the National Preparatory School during the firing with bazooka at the entrance door? Can anyone look at the opening of the 1968 Olympic Games as if nothing had happened?

Thinking also means developing a thing in its consequence, so we aspire to look at a sequential horizon of events concatenated for 48 years. A horizon, circumscribed by the memory that has been borrowed, that makes it possible to anticipate the abstract form of historicity and that comes from an ontology of the time-space link. In this sense, the Tlatelolco massacre is a history that is made, and continues to do, through categories of analysis that allow us to unveil the content of the consciousness of effective history.

Gadamer explains that memory (mneme) "everything which has been experienced sinks down and loses its presence - and yet, without ever being fully present, can none the less be repeated once again" [20]. Memory then implies inhabiting the Hades, so that remembering is that path that makes it possible to descend into the world of oblivion. To think the 68 then is to establish a dialogue with Mnemosyna, the goddess of the mneme, which makes it possible to assault Hades, to recover the knowledge that gives the unifying power and the solidity of memory. But here it is a knowledge that derives from experience that accumulates without ceasing [21]. What happens when my memories are not mine? "There are loves that last even for those who did not live them" [19], says Paco Ignacio Taibo II. The memory of 68 is one of those loves that awaken the question for the meaning of all things, but also about the place we have in the world.

Memory allows us to be habitual residents of the world of Hades, which allows us to appropriate the experience through the life that is remembered, lived in the imagination, and makes sense the knowledge we appropriate when we re-create the life story of the other which is a self, a complement to my existence, while we share the event of history that is re-lived through the memory. This sense makes history magistra vitae (teacher of life) [22], a kind of wisdom and memory of life. 


\section{FORGETFULNESS, THOUGHT AND MEMORY}

Forgetfulness, thought and memory; categories, that make of the student movement of 1968, a ghost that revolves in the Mexican imaginary. In the Mexican cultural tradition, they give meaning to the world and make it possible to deduce the influence of the Tlatelolco massacre in contemporary Mexico. They also make it possible to seek the real, historical being of the spirit of 68 through the analysis of a becoming that was drowned in a bloodbath. Thus, the 68 is analyzed from an unfinished possibility that has become in future.

From where analyze the student movement of 1968 ? History is written in many ways, even from silence itself; a silence that still reveals a dismayed, rabid, murdered self twice. Rosario Castellanos points out: "Do not get into the files because nothing is recorded in the minutes" [23]. It is like the final solution in which it is tried to kill the before and the after of the human life, of the history of our life; and poses a challenge to philosophical thought. How to look at the one who has no face, who is in the world of the historical life of a culture, but in particular is not in the memorial of tradition, is not in consciousness?

"I remember, we remember" [23], says Rosario Castellanos. Remember is linked to memory, and it is shown as a form of thought, of logos, that is, of quest [20]. Throw it all, says Paco Ignacio Taibo II, and take a walk [19]. When we remember we seek in the world of Hades. If the memory is what one comes to mind, what erupts from the experience of tradition... what memory do we speak when we show the truth of the 1968 student movement in Mexico? Should we remember the killer? Is it better to remember the murdered? Phenomenical duality of the experience of silence: on the one hand it uncovers guilt and on the other, it becomes a word of death.

In the face of a life that arises facing the other, a light that in itself will be brief, tenuous, twinkling, Rosario asks: "And in that brief livid light, who is it? Who is killing? / Who are in agony, who are dying? / Who are the ones fleeing without shoes? / The ones who will end up in the jailpens? / The ones who are rotting in hospitals? / The ones who keep silent forever, out of fear?" [23].

Who kills silences and imposes his own silence from the scope of his guilt. That one that kills, who is? That, you are, is the other, is that one; is the one that reveals itself in the silence of a hospital where the agony is configured as the silent presence of death; or also, in the terror of one who flees; but, what does he flee from? Flee from death, from yourself or the other? The truth is that in his flight, he suffers the loss, not only of his life, of his shoes or of his voice, but also of consciousness; loses memory and reason. The story vanishes between his fingers, and when he looks at the body of the one he killed, bloodstained, deformed, with a face but without a brain, he asks himself: where are our dead?

\section{THE SUBJECT OF THE '68 MEXICAN: NOBODY}

To the question, where are our dead?, it precedes necessarily: who are those who have died? But when we ask the story about 68 , the first thing that arises is the anonymity of a voice that from its oblivion cries out: "Who? Who are they?" [23] Who does Rosario Castellanos ask to be answered: "No one"? [23] Who do you talk to? Who answers? Here we find two components of his thinking: the subject that descends to the world of Hades and the subject of nothingness.

To descend to Hades, one navigates the "river of eternal and shed blood that deposits fertile slime on the earth" [24] from oblivion to recover from abandonment to the unrecognized; extract it from desolation, bitterness and the "perpetual entrainment of life" [25]. The one who has not been recognized was sacrificed for history to grow on his corpse; his coffin will be the crucible of which will arise, immovable and immovable after the fusion of bones and flesh, his dreams concretized in his memorial.

The subject of nothing, or rather, nothing as a subject, is concretized in "nobody". No one is the confluence of the Cartesian subject and the Nietzschean subject. No one is the being who is without anchoring to the world of life thrown into it, standing before the raw autonomy of its freedom; is deprived of all psychological resonance and autobiographical reference, disconnected from its space-time referents, and has lost consciousness as a speaker, agent, character of narration and subject of moral imputation. It is a subject of ahistorical identity without meaning, which expresses the permanent possibility of being in front of nothing to discover it as the anguish of not being more.

It is therefore two subjects that are articulated by the time and space of the event: "The next day, no one" [23]. This implies that yesterday, "no one" had a name and identity, lived his life, existed, was someone. No one is today, who was himself yesterday and is named: he-died. The "No one" of Rosario Castellanos is the dialectic expression of the self that is another. No one is the one who died in 1968, the same that has remained in time for 48 years, that other is the same that is sought in every face, every trace, every encounter. A face that is, you. You is not on whom one can speak, on the contrary, it is to whom one speaks [26]; so that you can't "nothing without you, nothing without us".

In this sense, no one implies the opening of the solidarity bond of a self that says you, you who says I, and a self that in saying you affirms us. It is then, through the opening of self-forgetfulness; how can any other, be in an incessant chain of belonging to the event of listening to each other. When we hear the inhabitant of the 
world of Hades as an "other", by empathy becomes you. So, no one is a collective that acquires identity in the solidarity of its memorial inscribed on the tombstone of oblivion.

But there was no stone, for "The plaza dawned swept clean." [23] Nothing happened. In the "Memorandum on Tlatelolco", the presence of nothingness is reiterative as a possibility to show the non-being that is implicit in the negation of the most significant events in the life of man: birth and death. By means of a broom the destruction of life is swept away and cleansed.

And life is reiterated in its everyday indifferent to the event of the world of the other's life. The indifference that will lead to oblivion is circumscribed by silence; well: "the newspapers / featured the weather report" [23]. But it is not the weather report that has been lost after the smell of gunpowder and blood spilled. On the contrary, it is the weather of those who should not know, of those who do not know and will not know the events the day before. It is, then, time as a scheme of order and determination of the multiplicity of life, in an infinitely given structure, which is experienced as a limited sequence of events, concatenated towards a determined end.

However, time is, in reality, the foundation that sustains the event in which the present has its roots. Thus, the day after October 2 was shown as the empty vessel containing the heart and blood of the massacred youth, the chalice of human reality from which to emerge the riddled being, the murdered being-hope, to be silenced, the being-thrown to the bottom of a suspended reality.

"And on television, over the radio, at the movies, / there was not a single change of program, / no interrupting news flash or even a / moment of silence at the banquet. / (The banquet continued.)" [23]. The world is suspended in nothing, Sartre would say [27]. The reality of the events have been installed in the nothingness, limited to show what everyone hopes to know from an area where the world of life is presented as being nothing more [28].

There were no program changes or ads interspersed. Why should there be any changes? The events of the previous day were at first thrown into the world of Hades so that they emerge into nothingness beyond the world. That is why "not a minute of silence" because nothing will appear as a place with multiple edges that delimit all projects failed. More than 400 lives cut and thrown to nothing, 400 failed life projects that could not be realized as they were ripped out of life.

The possibility of being and becoming in a potentiality of realization through freedom was denied since 1968 to the Mexican youths. So, why keep "a minute of silence"? One minute of silence, 60 seconds of time, 6,000 milliseconds of attention to the other. There are biological phenomena that occur in fractions of milliseconds; a minute is an eternity for when it is understood that time is understood from the now. Today it is time to add the "now" lost in 1968 to widen the horizon of understanding from which one looks at human reality and recovers being different from what it is.

But the human reality can't be removed from the world of life, unless we pull it out of itself. And there are multiple ways to get it off. The painful path is what Mexico learned through history. The Mexican suffers in silence and the banquet continues. Life continued with its discourse, continued diluting as the grime is diluted in the laundry with the intention of reducing the existing, a series of events that are linked in a single aspect of human life: the daily life that makes the Infinite history a finite history.

When the 68 is analyzed from the horizon of a history written with blood and where it is unknown where are those who died; the memory is not confined to remember the being that was previously known in its existence and is now recovered in the memorial of an unfinished story that makes the absent present. "The essential thing -says Moratalla- is not only in retaining or in forgetting, but in internal tension, in that plastic force that allows us to place ourselves before the past as something that (whether we want it or not, think it or not) it is our own, it constitutes us and it throws us into the future" [29]. It is, then, to recover the being that underlies the tradition of the question that has been elaborated before and has disappeared in the silence of the silence that is self-censored, the silence that learned to remain silent in the darkness that surrounds the sense of action to ask from the historicity of the being of tradition.

Then, as Gadamer indicates, remembering being is the memory of a forgotten, forgotten question [30]. A question that transcends the "non-power-to-do" to attract to historical reason what is now asked and give meaning to ask [17], from a field of realization and praxis. The praxis of the question is shown as a moment that surpasses the historicity of thinking and knowing. As we journey through the painful path, we ask ourselves to understand the influence that the student movement of 68 has had in the historical tradition.

The 2 of October of 1968 taught to forget and to deny a history; to deny the identity of life and our thinking. He made oblivion, not only the omission of acting but also made it possible to realize the forgetfulness of what is, has been and will be. The "October 2 is not forgotten", states the ruling. Certainly, the historical memory does not forget the bloody events of that afternoon of October of 1968 in the Three Cultures Place. However, he forgot the possibility of being and doing from a context of social transformation.

From the anonymity of the otherness, the 68 left in the forgetfulness to the being that is realized in the human identity by means of the transformation of its historical and social environment. He made oblivion what 
Nietzsche calls: a condition of the life of the spirit [31]. It is our task, from the renewal of oblivion, to recover the capacity to look at the history of 68 with new eyes, so that the pathos that underlies the outcome of the student movement is familiar to the experience of silence that overflows the word.

\section{SUFFERING AND WATCHING MY OWN DEATH}

Mexico suffered the second day of October. Mexico continues to suffer. Now the State no longer murders the students, nor does it shoot the defenseless population. It has better mechanisms, finer strategies and we call it: poverty. The poor forget that he suffers, because he suffers in silence. That is why he does not need a minute of silence and demands a whole life of struggle. The one who suffers, whether in Auschwitz, Madrid $(11 \mathrm{M})$, Gaza, Africa, Asia, any other place where innocent victims are sacrificed, either through violence or poverty; Has almost as the worst of his suffering, suffering alone, in silence, forgotten.

The suffering is intensified by its incommunicability and the incomprehension that accompanies it. The suffering of the suffering is the concretion of the division of the immediate past and the present; a dense, deep, bleeding hole in the chest. It is a suffering that we do not understand because it is indecipherable. Before the suffering of the other, the image of what the student felt when he was brutally beaten lived as a bulge; only with vegetative functions. We also remember the student who was gunned down with the gun or the rifle, which is the one who is led to death on the wall; they look like scenes from a war of the past. But there is also the kidnapped student who lost his identity and watched his own death every day he remained alive. How do we look at our death? Dostoevsky recounts this experience in The Idiot in relation to the use of the guillotine [32].

In the Mexican 68, we look at death as you, but also as a self. Thus, Mexico looked at its own death; therefore, there were reasons to cry, because also everything was lost then. To understand the events and to mitigate the pain, initially resorted to a strong stoicism; but the events were never understood and the pain was not eliminated, nor should it be eliminated. That pain that the absent suffered was lost as his body and his life were lost along with his last rales in the deep vertigo of agony. Death is frightened by the agony that it implies, by the slow suffering that the human being is subjected during that last event of the reality in which it unfolds. As a last resort he used the prayer to ask the divinity to show himself unattainable, indulgence and serenity.

But the 68 also taught to fear the night. In Mexico, tragic events occur at night. The "sad night" in which Hernan Cortés grieves for his destiny marks the historical vision of the conquest of Mexico [33]. The night of Tlatelolco is the experience that constitutes the memory of contemporary Mexico, and for those who have lived in the memory of that endless dusk, it gives meaning to the permanent content of the experience of silence.

In Memorandum on Tlatelolco, Rosario Castellanos makes it clear that "Darkness engenders violence / and violence invokes darkness /to jell in crime" [23]. In the darkness, the courage of the one without faceless proclaiming the final solution of Auschwitz in the Mexican syncretism is sustained. "That is why October the second waited until night / so that no one saw the hand the clutched / the weapon, but only its sequel of lightning" [23]. A hand that first stretched out to the wind to offer the deception of a dialogue, the same hand that did not tremble to press the trigger of the rifle and thus, once more, death puts an end to the aspirations of the exercise of freedom in Mexico.

No one saw the homicidal hand, it was not necessary; the face was known by all, a face languished by the institutionalized ignominy that blinded the eyes of history behind the shining light of the shrapnel, and after the lightning fire that cut off life, the smell of gunpowder mingled with the ferrous stench of blood. "Ah, violence invokes darkness / because darkness engenders dream / and we can sleep dreaming that we can dream" [23].

Death is like a dream; And all dream, also the children and the old. Likewise, the dead have no age ... but where are our dead? Will they be dreaming of the ecstasy that leads to desolation and terror? No doubt they know in a dream that places them outside, testifying to the irresistible spell of history, what happened in the darkness of an October night. In the dream of forgetfulness and the fear that they take of the man when it walks towards the disaster, Rosario finds the cause of the Aztec suffering and says: "But here I touch an open wound: my memory. / It hurts, therefore it is true. It bleeds real blood. / Yet if I call it mine I betray them all" [23]. A history of betrayals shape contemporary Mexico. A Mexico painted red, that does not attend its wounds and although they continue bleeding, they evolve to scabs, where the death is anticipated like an inevitable event that will be realized under the gaze of the goddess Tlazolteotl [34], or the picture of Rogojin [32].

"Don't search for what is not here: clues, corpses. / Everything has been rendered as offering to a goddess: / to the Devourer of Excrement" [23] Only the memory remains, the memory of what has not been said, the text that nobody wrote or the one that was not read. How to look for, in the dream of sleepy history, the presence of those who died under the hand of ignominy? How to look for a body that does not exist, but was thrown into the Gulf of Mexico? How will it be possible to search for what is but is not? How to look for the footprint in a path that has not been traveled?

The corpse will resurrect in the memory that anticipates the dawning of the story of the other day. 
"This is our way of helping dawn to break / upon so many stained consciences, / upon an irate text, upon an open gate, / upon the face shielded behind the mask." [23] The other day where silence is the wisdom of oblivion when in the presence of the other, the otherness of the self is concretized. A self that remembers in company with you, a self and you who are at the dawn of history, the us who seeks in the consciousness of history the justice of a remember us. Thus, for Rosario Castellanos, our dead are in the being of history that is remembered under the protection of justice: "I remember, we must remember / until justice be done among us" [23].

\section{CONCLUSION}

What little is left of that October 2, 1968. After 48 years, if there is anything left, is the word of who survived the event; also live in the imagination the constructions of those realities, the true stories of each of the actors. The generations of the XXI century try to narrate the unspeakable, seek to recover the horror and translate it into words. Words that lose their essence, the blind and deep origin of cemetery; that is why many surviving victims are silent, refusing to tell the horrors they have experience.

In fact, the spectacle of the warp of the words with which the memory is worn is often disregarded. The martyrdom of the nameless innocents becomes political discussions, or justifications of one another, arguments, strategy and propaganda. In the end, the mantle of the years covers the initial horror, which is only a sham, a reflection of reflections that are lost in nothingness.

The historical being of the 68 , is a being who learned in the dark how fear comes from outside and drags the man to the Roman circus, where compassion is manifested in the desolation of the affection that invades the one who looks at the suffering. Since then we have seen a youth that bleeds and excretes fear along with the sweat that accompanies the chill; the blood freezes, the limbs numb, the non-action overwhelms us and the memory floods us with jolts of shudder.

As long as the pain is not overcome, the fragility of the body's weight will continue to be shown; the corpse will be observed, through the blackness of the night that surrounds the common grave. Fragility and blackness express in the Mexican imaginary, the loss of dignity, of hopes and young illusions, in short, of the most sacred. Only silence will remain. Mexico weeps in silence, suffers in silence and agonizes in silence. The silence, in the poem of Rosario Castellanos, envelops the victim in a halo of unreason, shows Tlatelolco as the field of annihilation that leaves life suspended but also death, and makes the situation-limit of living in the remembrance of 68 , the unity of many senses to understand us as a product of history.

At the end will remain in the kingdom of the mneme, the word not spoken. In the word there could be some rape or sacrilege, an irreverent attempt to remember forgetting. And it is that forgetfulness, the forgetfulness that beats in every word, that perhaps distresses the victim; an unfair and inconsiderate oblivion.

Avoiding oblivion, Rosario Castellanos transcends his criticism of violence, and not only denounces the injustice suffered by Mexican students in 1968, but also invites action. To remember is to establish a dialogue with the inner voice where it puts an end to the confusion between love and the scene of a brutal massacre. To remember is to do justice to everything denied; listening attentively to the echoes of the tradition that demand justice for death itself.

\section{REFERENCES}

[1] J.E. Westheider, The Vietnam war (Westport: Greenwood Press, 2007).

[2] M.M. Smith, The 'Revolt of the Black Athlete': Tommie Smith and John Carlos's 1968 Black Power Salute Reconsidered, in S. Wagg (Ed.), Myths and milestones in the History of sport (London: Palgrave Macmillan, 2011) 159-184.

[3] Office of the High Commissioned, United against racism, racial discrimination, xenophobia and related intolerance (New York: United Nations) 2012.

[4] UNESCO, Ethics for the $21^{\text {st }}$ century (Paris: UNESCO, 2001).

[5] A. Feenberg, and J. Freedman, When poetry ruled the street. The French may events of 1968 (New York: State University of New York Press, 2001).

[6] P. Peeva, 1968 Prague spring and Sofia summer, The International Journal of Civic, Political, and Community Studies, 13(4), 2015, 41-49.

[7] E. Poniatowska, La noche de Tlatelolco (Ciudad de México: Editorial Era, 1993).

[8] M. Pereira Hernández, Análisis de la simbólica apocalíptica en el arte: los cuatro jinetes, Horizonte de la Ciencia, 5(9), 2015, 103-124.

[9] E.S. Berry, The apocalypse of St. John (Columbus: John W. Winterish, 1921).

[10] V.M. Sanchis Amat, Entre Tlatelolco y Tlatelolco: voces de la poesía mexicana en torno al 2 de octubre de 1968, Telar, 13-14, 2015, 150-165.

[11] L. Melgar, Rosario Castellanos crítica de la violencia. Una aproximación, Revista Destiempos, 19(4), 2009, 395-412. 
[12] L.E. Zamudio, Pasaporte a la poesía de Rosario Castellanos, Revista Destiempos, 19(4), 2009, 316-330.

[13] F.X. Solé Zapatero, Rosario Castellanos. De Comitán a Jerusalén, Casa del Tiempo, 9(100), 2007, 42-48.

[14] C. Rodrigañez, Asalto al Hades. La rebelión de Edipo (Alicante: Hurpograf, S.L., 2004).

[15] S. Freud, Female sexuality, in J. Strachey (Ed.), Sigmund Freud. Collected Paper, Volume V (London: The Hogarth Press, 1950) 252-272.

[16] A. González, Harsh world and other poems (New Jersey: Princeton University Press, 2015).

[17] H-G. Gadamer, El problema de la conciencia histórica, 2a ed. (Madrid: Editorial Tecnos, 2001).

[18] H-G. Gadamer, La herencia de Hegel, in J. Grondin (Ed.), H-G. Gadamer, Antología (Salamanca: Ediciones Sígueme, 2001) 305-330.

[19] P.I. Taibo II, 68 (Ciudad de México: Joaquín Mortíz, 1991).

[20] H-G. Gadamer, The enigma of health (Stanford: Stanford University Press, 1997).

[21] H-G. Gadamer, El inicio de la filosofía occidental, 2a ed. (Madrid: Ediciones Paidos Ibérica, 1999).

[22] J. Grondin, The philosophy of Gadamer (Chesham: Acumen Publishing Limited, 2003).

[23] R. Castellanos, Memorandum on Tlatelolco, in M. Ahern (Ed.) A Rosario Castellanos reader: an antology of her poetry, short fiction, essays and drama (Austin: University of Texas Press, 1988) 98-99.

[24] R. Castellanos, Apuntes para una declaración de fe, in R. Castellanos, Poesía no eres tú (Ciudad de México: Fondo de Cultura Económica, 1975) 7-15.

[25] R. Castellanos, Trayectoria del polvo, in R. Castellanos, Poesía no eres tú (Ciudad de México: Fondo de Cultura Económica, 1975) 17-29.

[26] H-G. Gadamer, Truth and method (London: Continuum Publishing Group, 2006).

[27] J.P. Sartre, Being and nothingness: a phenomenological essay on ontology (New York: Pocket Books, 1978).

[28] M. Heidegger, Being and time (Oxford, UK: Blackwell Publisher Ltd, 2001).

[29] A.D. Moratalla, Introducción. Historia y filosofía en H.-G. Gadamer, in H-G. Gadamer, El problema de la conciencia histórica, $2^{\mathrm{a}}$ ed. (Madrid: Editorial Tecnos, 2001) 9-37 pp.

[30] H-G. Gadamer, Autopresentación de Hans-Georg Gadamer, in J. Grondin (Ed.), H-G. Gadamer, Antología (Salamanca: Ediciones Sígueme, 2001) 21-54.

[31] F. Nietzsche, Untimely meditations (Cambridge, UK: Cambridge University Press, 2007).

[32] F. Dostoieffsky, The idiot (London: S. Cowan \& Co., 1887).

[33] B. Díaz del Castillo, The history of conquest of New Spain (Albuquerque: University of New Mexico Press, 2008).

[34] M. Gajewska, Tlazolteotl, un ejemplo de la complejidad de las deidades mesoamericanas, Ab Initio, 4(11), 2015, 89-126. 